\title{
Editorial: 40th Anniversary of the Journal of Consumer Policy
}

Received: 13 February 2017 / Accepted: 14 February 2017 /

Published online: 16 March 2017

(C) Springer Science+Business Media New York 2017

Forty years ago, Folke Ölander, Norbert Reich, and Gerhard Scherhorn founded the Journal of Consumer Policy. Their vision was to combine scholarship on consumer issues from related disciplines in a single journal under the banner of consumer policy. This multidisciplinary approach to scholarship, then still in its infancy, has become the hallmark of research into all aspects of consumer matters.

It is with considerable pride that we celebrate the 40th anniversary of the Journal of Consumer Policy this year. The journal continues to be at the forefront of developments in consumer policy and law scholarship, and the former and current editors have laid solid foundations for the next 40 years of the journal.

\author{
Alan Mathios \\ Hans Micklitz \\ Lucia Reisch \\ John Thøgersen \\ Christian Twigg-Flesner
}

